University of Nebraska - Lincoln

DigitalCommons@University of Nebraska - Lincoln

Faculty Publications: Department of Teaching, Department of Teaching, Learning and Teacher Learning and Teacher Education

Education

2007

Student Experiences of a Culturally Sensitive Curriculum: Ethnic

Identity Development amid Conflicting Stories to Live By

Elaine Chan

Follow this and additional works at: https://digitalcommons.unl.edu/teachlearnfacpub

Part of the Curriculum and Instruction Commons, and the Teacher Education and Professional

Development Commons

This Article is brought to you for free and open access by the Department of Teaching, Learning and Teacher Education at DigitalCommons@University of Nebraska - Lincoln. It has been accepted for inclusion in Faculty Publications: Department of Teaching, Learning and Teacher Education by an authorized administrator of DigitalCommons@University of Nebraska - Lincoln. 


\title{
Student Experiences of a Culturally Sensitive Curriculum: Ethnic Identity Development amid Conflicting Stories to Live By
}

\author{
Elaine Chan
}

Department of Teaching, Learning, and Teacher Education, College of Education and Human Sciences, University of Nebraska-Lincoln, Lincoln, Nebraska, USA

\begin{abstract}
This study examines ways in which students' experiences of a culturally sensitive curriculum may contribute to their developing sense of ethnic identity. It uses a narrative inquiry approach to explore students' experiences of the interaction of culture and curriculum in a Canadian inner-city, middleschool context. It considers ways in which the curriculum may be interpreted as the intersection of the students' home and school cultures. Teachers, administrators, and other members of the school community made efforts to be accepting of the diverse ethnic, linguistic, and religious backgrounds that students brought to the school. However, examination of students' experiences of school curriculum events and activities revealed ways in which balancing affiliation to their home cultures while at the same time abiding by expectations of their teachers and peers in their school context could be difficult. The stories highlight ways in which curriculum activities and events may contribute to shaping the ethnic identity of students in ways not anticipated by teachers, administrators, and policymakers.
\end{abstract}

Keywords: curriculum, ethnic identity, multicultural education, narrative inquiry, student experience

\section{Introduction}

In a previous paper (Chan 2006), I examined the complications and challenges two teachers in a Canadian inner-city middle school in an immigrant neighborhood encountered in the process of developing and implementing a culturally sensitive curriculum. In this paper, I explore the same setting from the point of view of the students. For many students, their 
experiences of schooling dramatically foreground the contrasts between home cultures and other multicultures and, at a sensitive time in their lives, raise questions of who they are in a new country. Such questions around developing student ethnic identities are the focus of this paper. I explore ways in which participation in school curriculum events may contribute to shaping a sense of ethnic identity in students of ethnic-minority background.

I hope this paper will enhance the ability of educators to meet the needs of students of ethnic-minority backgrounds. The populations of North America, Europe, Australia, etc. are becoming increasingly diverse through immigration and the birth of children into immigrant families. Knowledge about student experiences has the potential to inform teaching practices, professional development for educators, and decision-making around curriculum policies for multicultural school contexts. The identity formation of ethnic, and indeed all, children is of crucial importance to the cultural shaping of multicultural communities and countries. The stories I present suggest some of the identity tensions experienced by students as they move among home, community, and multicultural school settings, and raise issues about the transmission of policy and the role of curriculum in shaping the identity of students of diverse backgrounds. The stories highlight the need to further explore ways in which the school curriculum contributes to shaping the ethnic identities of students.

\section{Examining cultural harmonies and tensions on a three-dimensional narrative inquiry space}

Many factors and forces contribute to students' development of ethnic identities. My interest is in the role played by school curriculum events, some, but not all, designed specifically for multicultural settings. I view student identity as a continuing narrative construction, understood in terms of cultural characteristics of the home and community combined with their ongoing interaction over time. Connelly and Clandinin (1999), writing on teacher identity, refer to identities as "stories to live by." For students, who they are and the stories they choose to live by are critical parts of their daily school lives.

Building on Dewey's (1938) notion of continuity and interaction as the defining conditions of experience, I frame my research in terms of student narrative histories and student social interactions. Student experiences are never studied in isolation. Rather a student's experience is unpacked in terms of its history (continuity) and in terms of others involved in the experience (interaction). Clandinin and Connelly (2000) use Dewey's (1938) notion of the structure of experience to formulate the idea of a three-dimensional narrative-inquiry space as a framework for analyzing stories of experience in terms of temporal, spatial, and social-personal influences.

When students come to school, they bring their home cultures, developed through interaction with family and community members. These cultural histories are never merely formal categories. Knowing that a child is "first-generation mainland Chinese" is insufficient for curriculum planning and for research. It is necessary to understand in some depth the particular narrative histories of each child in order to identify both his or her cultural group and his or her specific history.

I look at students in school curricular contexts. I explore students' experiences of interacting with other members of their school community and examine their, and their parents', 
responses to school curriculum events and activities. I examine in particular the tensions and harmonies (Clandinin and Connelly 2002) of interactions among individuals of diverse ethnic backgrounds in order to learn about the ways in which the customs, practices, and languages of the students' cultures play out in a school context and contribute to students' ethnic identity. I have not followed students into their communities and do not know how their sense of ethnic identity is shaped by interactions there. I have, however, caught glimpses of the ways in which students' ethnic communities may contribute to their responses to curriculum events as I have observed students interacting with their peers, teachers, and family members in the context of regular school events and classroom activities.

\section{Learning about student experiences using a narrative inquiry approach}

To learn about the students' "stories of experience" (Connelly and Clandinin 1988), I undertook participant observations on the Bay Street School landscape using a narrative inquiry approach (Clandinin and Connelly 1994, 2000). I began with a group of 7th-grade students in May 2000 and continued with the students to their graduation from the school at the end of their 8th-grade year in 2001. I then began with a second group of 7th-grade students and continued with them until they graduated in 2003. Interaction with the students and their teachers, William Jisko and Dave Rudman, about their experiences of the inclusion of culture in the curriculum occurred in the context of classroom and out-ofclassroom activities. I took part in all aspects of classroom life, attended student assemblies and field trips, and interacted with members of the school community at school-sponsored events such as "Multi-cultural Night" and "Curriculum Night" in order to learn about ways in which issues of ethnicity, culture, and language played out in the school context. ${ }^{1}$

Bay Street School is located in a Canadian inner-city, immigrant neighborhood (Connelly et al. 2003). Students speak 31 languages and dialects and represent 38 countries (Chan and Ross 2002). The teachers, administrators, and other members of the school community demonstrate a willingness to accommodate for the differences in perspective that may be associated with differences in religion and ethnicity. The curriculum may also be seen as culturally sensitive. Students choose from International Language (IL) classes in Cantonese or Mandarin Chinese, Vietnamese, Arabic, Swahili/Black History, or Spanish that are integrated into their regular school day. The choice of international languages offered reflected the significant ethnic and language groups in the school: Chinese, Vietnamese, Middle Eastern, Jamaican and Caribbean Black, Somalian, and Western European communities.

The teachers seemed willing to build opportunities to learn about different cultures into their classroom curricula. For example, William had his students interview their parents about their childhood in their home cultures and then write stories based on what they had learned. He incorporated into a social studies project a component that involved having the students work with their parents to learn to prepare ethnic foods that would later be shared with classmates in an International Food Fair.

The teachers and administrators were also supportive of schoolwide events such as "Multi-cultural Night." This event was held every year around the time that the Chinese and Vietnamese students celebrated the Lunar New Year with their families, the Muslim 
students celebrated the end of Ramadan, and all of the students began a new term. Students worked with their IL teachers to prepare songs and dances to perform during an evening event to which parents and members of the community were invited. The evening also included an ethnic food table organized by parents and grandparents from the Parent Centre.

There is an abundance of research highlighting the need for culturally relevant pedagogy (Villegas 1991, Ladson-Billings 1995, 2001) and culturally sensitive curricula that build on the experiences and knowledge that students of ethnic-minority background bring to a school context (Banks 1995, Igoa 1995, Cummins 1996). Much of this literature, however, is an examination of curriculum from a teacher perspective, illustrating ways in which students respond positively to initiatives to acknowledge or include the home cultures into the school context. There is a general tendency to overlook student voice (CookSather 2002), and studies in which an attempt is made to examine student response to school events, including examination of student voice and engagement in school reform, are relatively recent (see Rudduck et al. 1996, Mitra 2001, 2003). There is in particular a puzzling lack of research examining the curricular experiences of students of ethnic-minority background from the perspective of the students themselves. Bullough's (in press) examination of a Muslim student's response to curriculum and peer interactions in his US school is among the few examinations of school curriculum activities from the perspective of students of ethnic-minority background. Given the increasingly diverse population in North American schools (Chan and Ross 2002, He et al. in press), addressing the curriculum needs of students of ethnic-minority background is of high priority. Not only is the academic performance of this population at stake; their social development is also at stake.

Clandinin and Connelly (1996) distinguish between the teacher knowledge that is gained through personal and professional experience, and the knowledge that is gained through instruction or exposure to information through interaction with individuals, documents, materials, and other "expert" sources. A parallel distinction can be made of the terms "students' stories of curriculum experiences" and "stories of students' experiences of curriculum." Student experiences of curriculum events may differ significantly from teacher or parent perceptions of their experiences. Teachers bring experience gained through prior experiences of teaching and learning about what they deem appropriate for students of ethnic-minority background. Students also carry with them ideas about what to expect and how to respond, gained through their experiences of interaction with peers, teachers, and family members.

In this paper, I draw on student experiences to explore their responses to a culturally sensitive curriculum. Bay Street School had teachers, administrators, and parents who seemed to celebrate the diversity of their school community and seemed committed to including culture in the curriculum. I explore students' experiences of curriculum in the form of stories-The grade 8 graduation, The Family Studies lesson, and They call it "Multi-cultural Night" but it's really "Chinese New Year" - witnessed during school visits. These stories illustrate ways in which the inclusion of culture in the school curriculum may involve tensions that may contribute to ethnic identity formation in complicated ways. The grade 8 graduation highlights ways in which a curriculum event intended to celebrate all students became a source of tension between a student of ethnic-minority background and her 
parent. The Family Studies lesson highlights students' unexpected responses to their teacher's attempt to engage them in discussion about cultural differences as part of the regular school curriculum. They call it "Multi-cultural Night" but it's really "Chinese New Year" examines how student responses to a cultural activity suggest possible tensions between ethnic groups in the school. These stories revealed layers of complexity that their teachers and administrators had not anticipated.

\section{Student experiences of culture in their school context}

As I noted in an earlier paper drawing on my experience in Bay Street School, the school's staff members were very aware of the school's cultural mix (Chan 2006). Many activities in and out of classrooms were designed to acknowledge ethnic communities and strengthen cultural awareness of others and pride in each student's culture. However wellintentioned, some of these events evoked complicated, even conflicting, responses from students and their parents. I begin with The grade 8 graduation to introduce ways in which school events may reveal tensions as the students attempted to balance affiliation to their home culture while at the same time wanting to identify with their school culture.

\section{"The grade-8 graduation"}

The grade- 8 graduation ceremonies at Bay Street School took place in June 2001. All of the students and their parents were celebrated, and everyone was expected to attend. Yet this activity, aimed at celebrating all cultures in the school equally, was not without identityconflict for some of the students. The story is an example of ways in which a school event may highlight differences in practices, beliefs, and values between norms in the home culture and those in the school culture. These differences may show up as identity tensions for some children. In these cases, the story students choose to live by is in conflict with other stories to live by promoted in the home or the school.

On the evening of the graduation, following the official ceremonies, I mingled in the school yard with parents, students, and members of the staff, and helped the teachers keep students from going into the gymnasium before it had been prepared for the dinner part of the graduation celebrations. I saw that Fatima, one of William's female Muslim students who had graduated that evening, was deep in discussion with her mother. I could hear only segments of their conversation and I do not understand Somali. ${ }^{2}$ I later recorded the following field note:

I looked over to see Fatima and her mother near the showcase to the right of the main entrance to the gymnasium. Both were leaning slightly forward, deep in conversation and seemingly oblivious to the crowds of parents, students, and teachers moving into the front hallway from the school yard or from the school yard into the hallway. Fatima was wearing a frothy-looking, pastel pink skirt and matching top, and she was not wearing the hijab that she usually wore to school. Instead, her hair was swept up and she was wearing make-up. Her mother, in contrast, was wearing a somber-colored hijab with a shawl, although her skirt was more formal than I've seen other mothers wear during a regular 
school day. The graduation ceremonies had already concluded and the tables [in the gymnasium] were arranged in a semicircle formation along the walls toward the back for the dinner and dance. There was music coming from the stage at the front of the gymnasium where the speakers had been set up.

I could overhear parts of their conversation from where I was talking with $\mathrm{Mr}$. Jisko and Ms. Ray. Fatima's mother was speaking mostly in Somali with some sentences in English while Fatima was responding mostly in English. "Please," Fatima pleaded. "I really want to go. They're all going. Please." Fatima, usually very verbal, loud, and often confrontational, was speaking in a subdued tone. Her mother said some more in Somali, and after a brief pause, said, "And the teachers will be there?" Fatima nodded, still looking very serious. "Yes. And it will end at 10:00 p.m. I can go home with Miriam and Sahra." It seemed that her mother was going to let her stay for the party. (Field notes, 18 June 2001)

From the English segments I caught as I moved back and forth from the hallway to the schoolyard, it seemed that she was negotiating permission to take part in the graduation party. I already knew that Fatima wanted to go to the party from an interaction I had overheard during class a few weeks earlier. Fatima had told her friends, Miriam and Sahra, that Ms. Steadman, the school principal, Ms. Ray, and Mr. Jisko (William) had told her that she needed to watch her behavior if she did not want to have her invitation to the dinner and dance that would follow the official graduation ceremonies withheld (Field notes, June 2001). William had later said that the middle-school teachers and the administrators had decided to present the graduation party and dance as a privilege that could be denied if students did not behave according to school rules.

The establishment and implementation of this new school rule also highlighted ways in which across-the-board and individually focused policies may be perceived as targeting some students - namely, students who often misbehave in school-and members of some ethnic or racial groups - namely, a few of the Black students who were punished for inappropriate behavior in school more often than others. This raised the issue of the interaction of culture and policy in ways that play out in very complicated and sometimes volatile ways in school and community contexts. The recognition that policies may have an effect opposite to intended highlights the need for examination of ways in which policies are experienced by individuals of ethnic-minority background in multicultural societies.

Earlier that year there had been labor actions by both the support-staff union and the teachers' union. The teachers did not work beyond their regular teaching responsibilities. Many of the students had begun to cut classes when they realized that their teachers would not be watching them as closely as usual. In addition, the school principal, whom Fatima and her same-grade peers had known since early in their primary-school years, had unexpectedly resigned and a new school administrator had arrived. All of these events combined to disrupt the students' usual school schedules.

In addition, the new principal had identified a need to discipline the students more severely than they had been accustomed to with the previous principal. Many of the students, already out of a regular pattern due to the labor actions, also seemed to be testing their boundaries by cutting classes toward the end of the school year and refusing to listen 
or to work quietly in class when they attended. The teachers, exhausted from disruptions during the school year and still adjusting to the many changes that had recently occurred at the school, felt the need to control the students' behavior by establishing consequences for misconduct. Many of the students, including Fatima, found themselves faced with consequences for misbehavior connected to their participation in the graduation celebrations. Although all of the students who had completed the academic requirements needed to graduate would take part in the official graduation ceremonies, they were told that only those who had complied with rules and regulations for behavior in school would receive an invitation to the dinner and dance that would follow the ceremonies.

Fatima was one of the students in her 8th-grade classroom who sometimes cut classes and challenged her teachers by speaking back to them. Her teachers had communicated with her mother about her misbehavior and knew that her mother supported their attempts to discipline her in school. Fatima had told Miriam and Sahra that she needed to watch her behavior. This interaction also made it clear that Fatima wanted to attend the graduation dinner and dance.

The school story of Fatima's relationship with her mother, from the perspective of the 7th- and 8th-grade teachers and the administrators who were involved in disciplining her, was that Fatima's mother was very strict with her. Marla, the special education teacher in Fatima's classroom, said that as a result of her interactions with her mother and from what Fatima had said about her mother in school, she knew that Fatima's mother often denied her permission to participate in school activities. The teachers and administrators sometimes reminded Fatima of her mother's strictness as a means of curbing her misbehavior in class and around the school. The scene I witnessed between Fatima and her mother on the night of the graduation was no doubt a reflection of the school story of Fatima and her mother.

I interpreted the interaction between Fatima and her mother to be a negotiation of conditions under which Fatima's mother would permit her to stay for the graduation dinner and dance. I had seen Fatima scowling earlier in the conversation, and I had heard her say the words "party" and "dance" along with the other (Somali) words that I did not understand. I heard her mother say, toward the end of the conversation, in English, "And the teachers will be there?" I saw Fatima lean in to kiss her mother's cheek at the end of the conversation, and later I saw Fatima at the party.

The incident is an example of ways in which Fatima, a first-generation Somalian student, may be caught in the middle, wanting to participate in what her non-Muslim peers were doing while at the same time needing to adhere to her mother's beliefs about activities she viewed as appropriate. Dances and parties are a common way of celebrating graduations in Canadian schools but Fatima's mother, who was born and raised in Somalia, often did not permit Fatima to attend parties with her friends on weekends or to take part in special events involving dancing and loud music, such as the school dances. Perhaps she was not certain that a party with dancing was an appropriate activity for her daughter. Fatima's friend, Sahra, whose family is also Muslim, is not permitted to participate in swimming classes, field trips, or school dances.

I wondered about the ways in which the limitations the students' parents placed on their participation in school activities might contribute to shaping their sense of identity as 
Muslim Canadians. Fatima, Sahra, and Miriam know that their parents have rules about their participation in activities that their non-Muslim peers take part in. I wondered whether Fatima and Sahra thought of their religious and cultural beliefs as a hindrance or an obstacle to being able to participate in enjoyable activities, or whether Fatima thought that her mother was unreasonable for wanting to refuse her permission to attend her grade- 8 graduation party.

I also wondered whether her mother, who was guided by different stories to live by, found Fatima rebellious or out of control in her requests to take part in activities that her peers were participating in. I do not know the reasons for their parents' decisions, but imagine that it would be difficult for Fatima and Sahra not to feel resentful when they see their peers participating in enjoyable activities they are forbidden to take part in, or realize that some of their peers have more freedom to take part in activities not permitted in their families. Some of the female Muslim students did not complain in a public way about their parents' rules, explaining to teachers or peers who asked that their parents do not allow them to take part in some activities. However, Fatima and Sahra seemed to want to take part in some of these activities; at the same time, they seemed reluctant to ask their parents for permission. In some instances, Fatima participated without telling her mother when the activities did not require written parental permission. Perhaps she viewed this approach as the most effective way for her to do what she wanted without angering or confronting her mother. As for her teachers, they seemed to support parental wishes for their children not to take part in some activities, but they also have their own stories to live by (Chan 2006).

The Grade 8 graduation story reveals ways in which a curriculum event may contribute to the ethnic identity-formation of students of ethnic-minority background in ways not anticipated by their teachers or administrators. A seemingly culturally neutral school event may introduce differences in the stories to live by of parents whose values and beliefs have been shaped by schooling experiences in their home countries, and their children who are being educated in Canadian schools. The story reveals ways in which balancing affiliation to the home culture while at the same time abiding by expectations of peer groups in their school context might have been difficult for Fatima and her classmates who are growing up in immigrant families. Given the potential of experience to contribute to shaping a sense of ethnic identity, school experiences that involve conflicting messages around the value of curriculum events may further complicate the students' developing stories to live by. They may place them in a difficult position at the nexus of differing and sometimes conflicting stories to live by and contribute to shaping their sense of ethnic identity. The curriculum may be perceived as the intersection of school narratives and histories that differ significantly for students, teachers, and parents.

\section{"The Family Studies lesson"}

The Grade 8 graduation was an examination of ways in which a school event that was intended to celebrate student achievement equally, without regard to cultural background, was a source of conflict for a student and her parent. In the following story, I examine how one teacher's attempt to incorporate culture into the curriculum, by engaging his students in discussions of cultural differences, seemed to be met with disinterest. I explore ways in 
which the interaction of social narratives of the students and their teacher may have played out in the development, implementation, and assessment of this curriculum event. The story reveals how a culturally sensitive curriculum may be difficult to achieve. Individuals bring with them social and personal narratives that interact to shape how the curriculum will play out.

On a Friday afternoon in late September, I sat at the side of a classroom, observing ... a Family Studies lesson. William was asking the students to name foods that they eat at home, and then to identify the cooking terms used to prepare the food. A student from the opposite side of the room called out "pizza," and William asked her about the cooking terms needed to prepare the food. She responded that it is baked. Another student called out "french fries" and then said that they are fried. Someone said "spaghetti," and the students called out "boiling" and "heating," "frying the meat and vegetables for the sauce." Answers came from all directions around the classroom.

William was trying to ignore the answers that were being offered from students who had not raised their hands and attempted to calm the students with a high five, a signal that students need to have their eyes up, mouths closed, hands empty, sitting straight, and listening. He called on someone directly in front of him. The boy said "pancakes," and others offered "frying," "baking." William called out, "Don't you guys eat ethnic foods? I eat perogies, dumplings, and falafel ..." (Field notes, October, 2000)

William, Dave, and many of the other teachers with whom I spoke at Bay Street School seemed enthusiastic about acknowledging and including the home cultures of their students in the school context. The students, however, did not always seem receptive to discussing culture in the classroom.

Reflection upon the Family Studies lesson fed my ongoing inquiry into how individuals of ethnic-minority cultures may experience tensions associated with balancing affiliation to both their home culture and their school culture. As I listened to William talk about foods, I was reminded of the difficulties teachers may face as they attempt to acknowledge the diversity of their students in their curriculum and in their practices. I celebrated William's comments that ethnic foods should be included among those the students discussed in class. As a researcher, I appreciate the unique qualities that become apparent when differences in culture and ethnicity are explored. I am fascinated by the rationale or the social history underlying the differences. As a teacher, I try to draw the differences out because I want to instill in my students an appreciation for diversity.

However, interaction with the students to learn about their experiences of culture in the curriculum revealed layers of meaning that were not initially apparent. To begin with, the responses to their teacher's question suggested that they might have been providing answers they viewed as acceptable or expected rather than answers that reflected their families' practices around food choice. With such a culturally diverse group of students, it is likely that the students are not eating french fries, pizza, spaghetti, and pancakes at home. Through conversations with the students at lunches and during class activities, such as the 
International Food Fair when they brought food they had prepared at home to share with their classmates, I had some insight into what the students are eating at home. Given the environment of Bay Street School, I wondered why the students did not call out the names of foods their own families eat at home. Did they not view talking about or acknowledging cultural differences to be part of the school curriculum? Were they embarrassed by what they ate at home? Did they want to give the impression that they ate what they perceived their peers to be eating? Were they behaving like sullen teenagers, uninterested in their lessons?

However, at the same time, I know that what I see in the teaching of my teacher-participants is shaped by my own experiences as a student and learner. I was reminded of my experiences as a child of ethnic-minority background, attending school in a community that was less culturally diverse than that of Bay Street School. Cultural diversity was not acknowledged in my school settings. As a student and as a teacher, I had seen children refuse to eat food that their parents had given them because it looked different from what their peers were eating. Food was a symbol of difference and, as a child, I did not want to be different from my peers in any way. I wondered whether this was the reason for some of William's students not wanting to discuss the food they ate at home. However, my childhood was in a culturally homogeneous setting where I was among the small number of individuals of ethnic-minority background. I expected that tolerance and appreciation for cultural diversity would be a natural consequence of interaction among the culturally diverse student population of Bay Street School.

Following the Family Studies lesson I described earlier, William assigned an International Menus project. The students were required to work in groups of peers of different ethnic backgrounds to learn about the history and culture of a country of their choice, and then present a profile of the selected country, create a menu of foods commonly eaten in the country, and prepare one of the dishes for an International Food Fair. He encouraged the students to choose any country that interested them, including the country of their family's origin.

William deliberately placed the students into groups that required them to work with peers of different ethnic backgrounds to encourage interactions about different foods, customs, and cultures. I interpreted the project to be an attempt to provide students with an opportunity to learn about foods from different countries. When I asked William about his goals for the unit, he confirmed that he was attempting to instill a sense of awareness of and an appreciation for cultural differences in his students by providing them with opportunities to learn about foods from different countries.

The students were initially hesitant to try foods they had not seen or tasted previously, and the students who had prepared the foods were hesitant to encourage their peers to try them. They seemed worried that their peers would reject their foods. Once a few of the students, especially those who were more boisterous and popular among their peers, had tried them and declared them to be acceptable, the students, overall, became much more willing to sample the foods. From watching the students rush from table to table to sample foods at the International Food Fair, it seemed that William's goals of exposing the students to a wider range of ethnic foods and providing them with the opportunity to try the new foods was a success. 
The incident highlighted possible obstacles to including culture in a curriculum. William's initial attempt to engage his students in discussion about cultural differences was met with nonparticipation. Not knowing specific reasons for the students' reluctance, he explored possibilities for following up on the lesson and decided to include a cultural activity that might expose them to diversity in a way more compatible with their interests. In the end, he met his goal in that the students seemed to enjoy the activity. This event demonstrated ways in which students' responses to their teacher's attempt to diversify the curriculum led their teacher to explore alternative means of encouraging them to share their culture.

\section{“They call it 'Multi-cultural Night' but it's really Chinese New Year"}

In the next story I explore ways in which student responses to their teacher's attempt to include culture in their school context revealed possible tensions and complexities of interaction among students of various ethnic groups. I begin with reference to a story, The Chinese New Year ribbon dance story (see Chan 2003), to set the background for a discussion of the surprising student responses to their peers' Multi-cultural Night performance.

The Chinese New Year ribbon dance was performed by six 7th- and 8th-grade female students of Chinese descent for the principal's retirement party. It was an enormous success from the perspective of many students, teachers, and administrators at the school. As I stood next to William and Dave and watched their students perform, I felt very proud and think that they did as well. The students, however, did not seem especially interested in talking about their performance or their participation in a neighborhood dance troupe, although I knew from talking with Marla, the special education teacher, that they often performed for community functions and seemed to enjoy it. My attempts to engage the students in conversation about their performance yielded seemingly ambivalent responses, suggesting that they had felt uncomfortable with the performance.

I was uncertain whether this discomfort was the result of embarrassment about being the center of attention, embarrassment about their affiliation to their home culture in a very public way, or some other reason. I was initially confused by this reluctance. It was only in hindsight, as I reflected upon my own feelings of embarrassment as a child when other children asked me about aspects of Chinese culture, that I began to realize that there might be underlying feelings of embarrassment among these students. However, I had thought that in a school context where diversity seemed to be acknowledged and celebrated, the students would be eager, or at least comfortable, talking about their home culture. Moreover, the comments of some other students revealed possible tensions between students of different ethnic groups. I explore these tensions in this follow-up story, "They call it 'Multicultural Night' but it's really 'Chinese New Year'":

We were in the small room off Room 42 today working on autobiographical stories. Rhea and Miriam were in the room helping me organize a list of questions to ask one another. We heard a knock on the door, and then a muffled voice, calling in urgently for us to open the door. When I opened the door, Lisa [a friend of Rhea's] rushed into the room, complaining about the noise in the classroom. 
William was absent today and the supply teacher did not seem especially concerned that students were seeping into the hallways and being quite noisy.

I was in the middle of asking Rhea and Miriam about what they thought of the cultural events that were included in school celebrations. They didn't know what I meant at first, and I gave them some examples. "You know, things like 'Multicultural Night' or IL class." Rhea, who was born in Jamaica and came to Canada as a 4-year-old, said to Lisa, who was born in Canada into a Chinese immigrant family, "They call it 'Multi-cultural Night' but it's really 'Chinese New Year'." Lisa responded to Rhea's complaints about "Multicultural Night" being "Chinese New Year" by asking her why she didn't take Swahili/Black History class and perform for Multi-cultural Night with other students from the class. Rhea shrugged her shoulders and didn't say anything at first, then began to complain about how she had not wanted to be in Swahili/Black History class because the teacher was "really mean." (Field notes, April 2003)

I thought about the reasons that Rhea might have for complaining about the representation of Chinese culture in the annual Multi-cultural Night. The predominance of the Chinese culture reflects the large Chinese population at Bay Street School. This accounts for the large Cantonese and Mandarin classes and the availability of resources in the community in the form of decorations, costumes, and teachers to organize cultural activities and events. A large proportion of families who use the Parent Centre and participate in Family Math evenings and the Multi-cultural Night are Chinese.

While the Black community is also relatively active in the community and in securing the availability of youth programs in the school neighborhood, there are some Black parents in the school community who feel that they need to be very vocal to ensure that the interests of Black students are not overlooked. These parents are active in the School Council, contribute to the planning of events for Black History Month, and demonstrate support for the Swahili/Black History classes that are a part of the IL program.

As I reflected back upon this story, I realized the extent to which Lisa and Rhea's responses reflect both their social narratives as members of their respective ethnic communities as well as their personal narratives as shaped by their individual temperaments. Both communities have long histories in Canadian society. Rhea was born in Jamaica and came to Canada as a 4-year-old while Lisa was born into a Chinese Canadian immigrant family. Rhea's comment suggested resentment that she had not been given the opportunity to perform for Multicultural Night. Their interaction revealed the extent to which individual experiences of culture in the curriculum may also be connected to the histories of the ethnic communities of which they are part.

This brief interaction brought to life issues associated with the inclusion of culture in the curriculum and invites discussion of the pragmatic issues around the implementation of a culturally sensitive curriculum. I wondered about the root of Rhea's comment? Did she feel excluded because her IL class did not perform for Multicultural Night? Was she resentful because she had wanted to perform? Were Rhea's comments a reflection of ways in which some members of the Black community at Bay Street School have felt discriminated against, leading to a feeling that they needed to fight for resources? Is her comment 
to Lisa an example of her willingness to challenge existing practices that she does not feel are fair to her? Do other Black students at the school feel that Chinese culture is portrayed in a more obvious way than Black culture? Do the Arabic and Vietnamese IL students think that the Chinese population dominates - it is more obviously represented than other ethnic groups within the school? Rhea's exclusion from the Multi-cultural Night performances could be also attributed, at least in part, to her decision to take Spanish rather than Swahili/Black History class. To what extent is her nonparticipation pragmatic, and to what extent could it be viewed as favoritism or deliberate exclusion?

Despite the potential for tensions between Lisa and Rhea as illustrated in the story just presented, the girls seem to get along relatively well. In interactions I have overheard and been a part of, I have seen them laugh about jokes and express their ideas and opinions, even when they differed, without seeming to worry that these views might lead to a termination of their friendship. Their relationship is an interesting contradiction in some ways, given the potential for tension between the two girls. It highlights the need for further exploration of the interaction of diverse cultures on a school landscape.

This conversation also raised questions about the role of teachers and the ways in which culture needs to be presented, and represented, in school contexts. To what extent does a culturally sensitive curriculum need to reflect the culture-groups represented in the school? Is it sufficient to present curriculum as a means of learning about diversity in general? Can it be said that the program for Multicultural Night was inadequate when Rhea had been given the opportunity to perform but had chosen not to take it? How is a school community to accommodate members of a culture-group who are interested in participating in cultural events while others of the same culture group are not? There is a need to explore further experiences and the implications for those involved.

The interaction also raises questions about the ways in which the inclusion of culture in the curriculum may contribute to shaping a sense of ethnic identity for the students. What was Rhea learning about her ethnic group when she made the decision to take Spanish rather than Swahili/Black history? What was she learning about the place of her ethnic group in relation to the ethnic groups of her peers when she noticed that students in the Swahili/Black History class wore relatively plain, brown costumes when compared to her Vietnamese and Chinese peers who had worn elaborate and brightly colored silk costumes for their performances? Did other students notice this as well, and what did they think?

At one end a need to acknowledge the diversity of students in a school context has been widely recognized. Acknowledgement of diversity is important in multicultural societies, and there is an assumption that people are happier, and more fulfilled, when their home cultures are recognized. The teachers at Bay Street School may have taken it for granted that the students and their families would want their home cultures recognized in the school context and that acknowledging the diversity of their students in and through school events and activities would be positively received by them. I saw complications to achieving this goal and suggest that this assumption may not be appropriate, at least for some of the students featured here. These complexities and tensions, and perhaps the importance of treading lightly, need to be acknowledged by curriculum specialists and policymakers. 


\section{Multiculturalism and equity policies}

The stories presented here reveal a gap between the policies guiding the inclusion of culture in the school curriculum and the experiences lived by students in a school community. Given the potential for curriculum events to shape the ethnic identity of the students involved, there is a need to find ways in which practices, and policies supporting these practices, can be informed by the lived experiences of students on diverse school landscapes.

The Canadian Multiculturalism Act states that:

the Government of Canada recognizes the diversity of Canadians as regards race, national or ethnic origin, colour and religion as a fundamental characteristic of Canadian society and is committed to a policy of multi-culturalism designed to preserve and enhance the multi-cultural heritage of Canadians in the economic, social, cultural, and political life of Canada.

Similarly, the Canadian Charter of Rights and Freedoms states that,

Every individual is equal before and under the law and has the right to the equal protection and equal benefit of the law without discrimination and, in particular, without discrimination based on race, national or ethnic origin, colour, religion, sex, age or mental or physical disability.

This fundamental belief in the importance of equity of opportunity of all students is recognized in the Equity Foundation adopted by the Toronto District School Board, and implemented in Bay Street School:

The Toronto District School Board values the contribution of all members of our diverse community of students, staff, parents and community groups to our mission and goals. We believe that equity of opportunity, and equity of access to our programmes, services, and resources are critical to the achievement of successful outcomes for all those whom we serve, and for those who serve our school system....

The Board further recognizes that . . . inequitable treatment leads to educational, social and career outcomes that do not accurately reflect the abilities, experiences, and contributions of our students, our employees, and our parent and community partners. This inequitable treatment limits their future success and prevents them from making a full contribution to society. (Toronto District School Board 1999)

In other words, there is an expectation that teachers, administrators, and other members of school communities be accepting and tolerant of the diversity of their student population, and support policies that emphasize the importance of recognizing diversity by ensuring that all children have equal access to opportunities and privileges available. 
This perspective is widely supported. Moodley (1995: 817), for example, affirms the need for "information and awareness of the cultural backgrounds of pupils in order better to diagnose strengths, weaknesses, and differences in cognitive styles." Ada (1988), Cummins (1996), McCaleb (1994), and Igoa (1995) highlight the importance of acknowledging the diverse cultural knowledge that students bring to classroom and school contexts. Cummins (1996) and McCaleb (1994) consider some of the dangers of a failure to recognize in the school context the cultural communities from which students come. Fillmore (1991), Kouritzin (1999), and Rodriguez (1982) present compelling accounts of ways in which the failure to support the maintenance and development of maternal language proficiency for students of ethnic-minority background had significant consequences for their sense of ethnic identity and their sense of belonging in their families and their ethnic communities. Banks (1995) highlights the inclusion of culture in the curriculum as a means of helping students to develop positive racial attitudes.

The personal, professional, and societal benefits associated with welcoming diverse cultures and languages into school contexts are clear. Yet we also need to develop practical ways of interacting that accommodate for beliefs when they differ significantly, and to find ways of incorporating culture into the curriculum in ways that are relevant to the students involved. In the process of recognizing the rights of each individual to have their religious, ethnic, and racial affiliation recognized, tensions may develop when different, or sometimes conflicting, beliefs emerge. Stories, such as the Family Studies lesson, suggest that students may not want to have their home cultures the focus of attention in the school. Likewise, the students I presented in The Chinese New Year ribbon dance did not seem interested in elaborating upon their participation in their dance troupe (Chan 2006). The Grade 8 graduation suggests ways in which an event that teachers might intend as a celebration of all cultures may require students of ethnic-minority background to actively negotiate with their parents in order to take part. They call it "Multi-cultural Night" but it's really "Chinese New Year" illustrates that well-intended curriculum activities, supported by teachers, administrators, and some parents, may be experienced in complex ways by students. This story also raises the possibility of resentment between ethnic groups in a school and highlights the need for exploration of the challenges a multicultural society can pose to schools.

Curriculum may be experienced as the intersection of narratives as students balance affiliation to both their home and school cultures. The inclusion of culture in the curriculum highlights the complexity of this interaction of narratives. This reality suggests why attempts to reach a consensus about appropriate practices and curricula is so difficult. My stories offer glimpses of students' conflicting stories to live by as they participate in a curriculum that was developed and implemented by others, whose perspectives on curriculum and schooling are shaped by narratives very different from their own.

Acknowledgments - I must express my heartfelt thanks to F. Michael Connelly in the Department of Curriculum, Teaching and Learning of the Ontario Institute for Studies in Education at the University of Toronto and to D. Jean Clandinin at the Centre for Research for Teacher Education and Development of the University of Alberta for their ongoing contribution to my research experience.

This study was supported by a Social Sciences and Humanities Research Council (SSHRC) of Canada Doctoral Fellowship. It was embedded into Michael Connelly and Jean Clandinin's long- 
term SSHRC-supported program of research examining the diverse cultural stories that parents, teachers, and students bring to the knowledge landscape of an elementary school: "Landscapes in Motion; Landscapes in Transition" (Standard Research Grant 410-99-0390); “Landscapes in Transition; Negotiating Diverse Narratives of Experience: 'Intersecting Narratives'” (Standard Research Grant 410-2001-0107); “Cultural Harmonies and Tensions in Inner-City Canadian Schools” (Standard Research Grant 410-2003-0573); and "Educational Equity Policies: Successes, Incompatibilities and Unexpected Intergenerational Outcomes" (Multiculturalism Issues in Canada Programme 853-20040056, CID 8235).

\section{Notes}

1. Descriptive field notes and journal entries were made following classroom observations, participation in the classroom and school activities, and conversations with students and their teachers. Research journal entries, interview transcripts, field-note records, and all other data, including samples of student work, communication between homes and school, community announcements, and media reports, were entered into an existing research archive. The field notes for each visit covered 20 pages; I averaged two 3-hour visits a week over the 9 months of the school year, yielding a total of $\sim 1,080$ pages of notes for each year of the study.

2. I assumed that the exchanges between Fatima and her mother were in Somali.

\section{References}

Ada, A. F. (1988) The Pajaro Valley experience: working with Spanish-speaking parents to develop children's reading and writing skills in the home through the use of children's literature. In T. Skutnabb-Kangas and J. Cummins (eds), Minority Education: From Shame to Struggle (Clevedon, UK: Multilingual Matters), 223-238.

Banks, J. A. (1995) Multicultural education: its effects on students' racial and gender role attitudes. In J. A. Banks and C. A. McGee Banks (eds), Handbook of Research on Multicultural Education (Toronto, ON: Prentice-Hall International), 617-627.

Bullough, Jr., R. V. (in press) Ali: becoming a student-a life history. In D. Thiessen and A. CookSather (eds), International Handbook of Student Experience in Elementary and Secondary School (Dordrecht, The Netherlands: Kluwer).

Chan, E. (2003) Ethnic identity in transition: Chinese New Year through the years. Journal of Curriculum Studies, 35(4), 409-423.

Chan, E. (2006) Teacher experiences of culture in the curriculum. Journal of Curriculum Studies, 38(2), 161-176.

Chan, E. and Ross, V. (2002) Report on the ESL Survey. Sponsored by the ESL Workgroup in collaboration with the OISE/UT Narrative and Diversity Research Team. Toronto: Centre for Teacher Development, Ontario Institute for Studies in Education of the University of Toronto.

Clandinin, D. J. and Connelly, F. M. (1994) Personal experience methods. In N. K. Denzin and Y. S. Lincoln (eds), Handbook of Qualitative Research (Thousand Oaks, CA: Sage), 413-427.

Clandinin, D. J. and Connelly, F. M. (1996) Teachers' professional knowledge landscapes: teacher stories -stories of teachers-school stories-stories of schools. Educational Researcher, 25(3), 24-30.

Clandinin, D. J. and Connelly, F. M. (2000) Narrative Inquiry: Experience and Story in Qualitative Research (San Francisco, CA: Jossey-Bass). 
Clandinin, D. J. and Connelly, F. M. (2002) Intersecting narratives: cultural harmonies and tensions in inner-city urban Canadian schools. Proposal submitted to the Social Sciences and Humanities Research Council of Canada. October 2002.

Connelly, F. M. and Clandinin, D. J. (1988) Teachers as Curriculum Planners: Narratives of Experience (New York: Teachers College Press).

Connelly, F. M. and Clandinin, D. J. (1999) Stories to live by: teacher identities on a changing professional knowledge landscape. In F. M. Connelly and D. J. Clandinin (eds), Shaping a Professional Identity: Stories of Educational Practice (London, ON: Althouse Press), 114-132.

Connelly, F. M., Phillion, J. and He, M. F. (2003) An exploration of narrative inquiry into multiculturalism in education: reflecting on two decades of research in an inner-city Canadian community school. Curriculum Inquiry, 33(4), 363-384.

Cook-Sather, A. (2002) Authorizing students' perspectives: toward trust, dialogue, and change in education. Educational Researcher, 31(4), 3-14.

Cummins, J. (1996) Negotiating Identities: Education for Empowerment in a Diverse Society (Ontario, CA: California Association for Bilingual Education).

Dewey, J. (1938) Experience and Education (New York: Simon \& Schuster).

Fillmore, L. W. (1991) Language and cultural issues in the early education of language minority children. In S. L. Kagan (ed.), The Care and Education of America's Young Children: Obstacles and Opportunities. 90th Yearbook, Part 1, of the National Society for the Study of Education (Chicago: National Society for the Study of Education), 30-49.

He, M. F., Phillion, J., Chan, E., and Xu, S. (in press) Immigrant students' experience of curriculum. In F. M. Connelly, M. F. He and J. Phillion (eds), Handbook of Curriculum and Instruction (Thousand Oaks, CA: Sage).

Igoa, C. (1995) The Inner World of the Immigrant Child (New York: St. Martin's Press).

Kouritzin, S. G. (1999) Face[t]s of First Language Loss (Mahwah, NJ: Lawrence Erlbaum Associates).

Ladson-Billings, G. (1995) Multicultural teacher education: research, practice, and policy. In J. A. Banks and C. A. McGee Banks (eds), Handbook of Research on Multicultural Education (Toronto, ON: Prentice Hall), 747-759.

Ladson-Billings, G. (2001) Crossing over to Canaan: The Journey of New Teachers in Diverse Classrooms (San Francisco, CA: Jossey-Bass).

McCaleb, S. P. (1994) Building Communities of Learners: A Collaboration among Teachers, Students, Families and Community (New York: St. Martin's Press).

Mitra, D. L. (2001) Opening the floodgates: giving students a voice in school reform. Forum, 43(2), 91-94.

Mitra, D. L. (2003) Student voice in school reform: reframing student-teacher relationships. McGill Journal of Education, 38(2), 289-304.

Moodley, K. A. (1995) Multicultural education in Canada: historical development and current status. In J. A. Banks and C. McGee Banks (eds), Handbook of Research on Multicultural Education (New York: Macmillan), 801-817.

Rodriguez, R. (1982) Hunger of Memory: The Education of Richard Rodriguez: An Autobiography (Boston, MA: David R. Godine).

Rudduck, J., Chaplain, R. and Wallace, G. (1996) School Improvement: What Can Pupils Tell Us? (London: David Fulton). 
Toronto District School Board (1999) Equity Foundation Statement. Available online at: http://www .tdsb.on.ca/_site/ViewItem.asp?siteid=15 andmenuid=684andpageid=548, accessed 17 November 2005.

Villegas, A. M. (1991) Culturally Responsive Pedagogy for the 1990's and Beyond (Washington, DC: ERIC Clearinghouse on Teacher Education, American Association of Colleges of Teacher Education). ERIC ED 339698.

\section{Author Biography}

Elaine Chan is an assistant professor of diversity and curriculum studies in the Department of Teaching, Learning, and Teacher Education, College of Education and Human Sciences, University of Nebraska-Lincoln, 24 Henzlik Hall, Lincoln, NE 68588-0355, USA; email: echan2@unl.edu. She has research interests in the ethnic identities of first- and second-generation Canadians, the interaction of culture and curriculum in school contexts, and student and teacher experiences of educational equity policies on multicultural school landscapes. 